\title{
Short term fluctuations of zooplankton abundance during autumn circulation in two reservoirs with contrasting trophic state
}

\author{
Gema Parra ${ }^{1}$, Nuno G. Matias ${ }^{2}$, Francisco Guerrero ${ }^{1, *}$ and $\mathrm{M}^{\mathrm{a}}$ José Boavida $^{2}$ \\ ${ }^{1}$ Departamento de Biología Animal, Biología Vegetal y Ecología, Universidad de Jaén, Campus de las Lagunillas \\ s/n, E-23071 Jaén, Spain. gparra@ujaen.es \\ ${ }^{2}$ Departamento de Biologia Animal and Centro de Biologia Ambiental, Universidade de Lisboa, Campo Grande \\ C2, 1749-016 Lisboa, Portugal.nunogonca@hotmail.com. mjboavida@fc.ul.pt \\ *Corresponding author: fguerre@ujaen.es
}

Received: $1 / 10 / 08$

Accepted: 28/1/09

\begin{abstract}
Short term fluctuations of zooplankton abundance during autumn circulation in two reservoirs with contrasting trophic state

Zooplankton community in the reservoirs of Maranhão and Santa Luzia (Portugal) were studied during the autumn stratification breakdown and the weeks before it. The results from water transparency, chlorophyll- $a$ and total phosphorus concentrations, calanoid to cyclopoid copepods ratio and zooplankton abundance confirm the different trophic state of both studied reservoirs: mesotrophic-eutrophic (Maranhão) and oligotrophic-mesotrophic (Santa Luzia), as previous studies have reported. Using Copidodiaptomus numidicus to compare both studied reservoirs, we found higher egg production rates in Maranhão than in Santa Luzia. Nevertheless, no relationship was ever found between zooplankton (abundance or egg production rate) and environmental variables (temperature and chlorophyll- $a$ ), which may suggest that wide and complex range of factors, abiotic as much as biotic, are involved in zooplankton dynamics during the autumn circulation period.
\end{abstract}

Key words: Reservoirs, copepods, trophic status, stratification breakdown.

\section{RESUMEN}

Fluctuaciones a corto plazo en la abundancia de zooplancton durante la circulación otoñal en dos embalses con diferente estado trófico

La comunidad zooplanctónica de los embalses de Maranhão y Santa Luzia (Portugal) fue estudiada durante la ruptura de la estratificación otoñal y las semanas previas. Los resultados de transparencia del agua, concentración de clorofila-a y concentración de fósforo total, así como la razón entre copépodos calanoides y ciclopoides y la abundancia de zooplancton confirman el diferente estado trófico entre ambos embalses: mesotrófico-eutrófico (Maranhão) y oligotrófico-mesotrófico (Santa Luzia), como estudios previos habían mostrado. Utilizando al copépodo Copidodiaptomus numidicus para comparar ambos embalses, se ha observado una mayor tasa de producción de huevos en Maranhão que en Santa Luzia. Sin embargo, en ningún caso se ha encontrado una relación entre el zooplancton (abundancia o tasa de producción de huevos) y las variables ambientales (temperatura y concentración de clorofila-a), por lo que se sugiere que una amplia y compleja gama de factores, tanto bióticos como abióticos, deben de estar involucrados en la dinámica del zooplancton durante el periodo de circulación otoñal.

Palabras clave: Embalses, copépodos, estado trófico, ruptura de la estratificación. 


\section{INTRODUCTION}

Since a substantial part of the energy flow in aquatic ecosystems is mediated by zooplankton and more specifically by copepods, variation in these populations could give useful information about changes occurring in the ecosystem. In particular, modifications in zooplankton populations have been described that can be affected by biotic and abiotic factors, temperature and food availability being the most obvious environmental aspects that might operate population changes (e.g. Rodríguez et al., 1995; Guerrero et al., 1997; Jiménez-Melero et al., 2005; 2007).

The majority of these studies are developed over annual or seasonal temporal scales, but there is a lack of research about the effects of autumn circulation on zooplankton dynamics (Andrew \& Fitzsimmons, 1992; Fussmann, 1993; ÁlvarezCobelas et al., 2006a). Moreover, these studies have been carried out mainly on lakes but, as far as we know, only one study, up to date, (Robarts et al., 1982) has been performed in order to identify the factors that control zooplankton dynamics on a short-term scale on reservoirs. However, no studies have been performed in order to know if there is any effect of the trophic state on zooplankton dynamics during this period. So, the main purpose of the present paper is to analyze the short-term changes in zooplankton community, mainly focused on copepods, in two reservoirs with contrasting trophic state during the breakdown of thermal stratification, a period in which frequent drastic changes are expected to occur in reservoirs.

\section{STUDY SITES}

Maranhão (130 m a.s.1.) and Santa Luzia (656 m a.s.1.) reservoirs are large water bodies located in the south of Portugal in the drainage basin of the Tajo River (Fig. 1). Water volumes were $205.4 \times 10^{6} \mathrm{~m}^{3}$ and $53 \times 10^{6} \mathrm{~m}^{3}$, respectively, and maximum depth was $25 \mathrm{~m}$ in both reservoirs during the study period. The renewal time is 1.47 and 2.67 years in Maranhão and Santa Luzia, respectively. The selected reservoirs have been previously studied

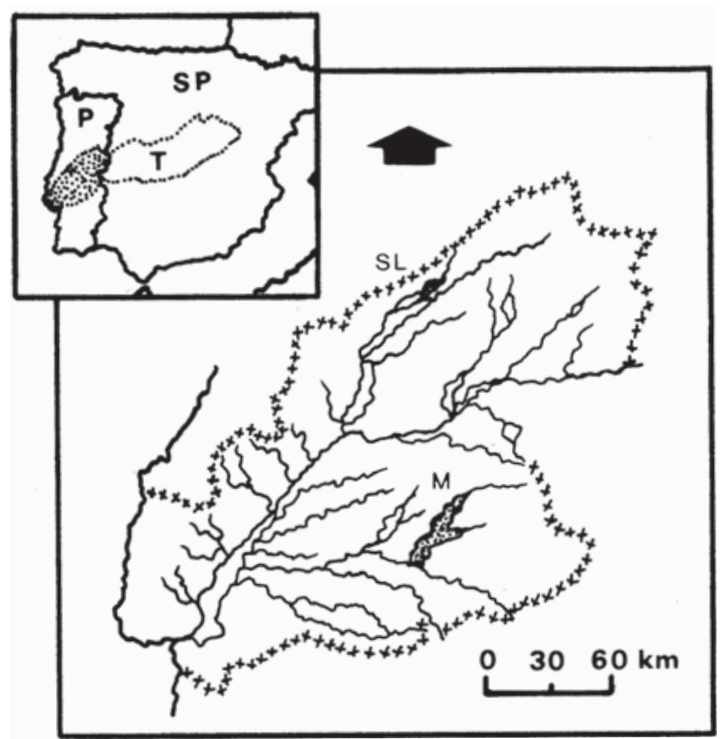

Figure 1. Location of the sampled reservoirs, Maranhão (M) and Santa Luzia (SL) in the River Tajo (T) watershed (Spain UJA, Portugal P). Localización de los embalses muestreados, Maranhão (M) y Santa Luzia (SL) en la cuenca del río Tajo (T; España UJA, Portugal P).

and described as mesotrophic-eutrophic (Maranhão) and oligotrophic-mesotrophic (Santa Luzia) (Brogueira \& Pereira, 1988; Marques \& Boavida, 1993; 1997). Both reservoirs can be considered as warm monomictic systems with stable thermal stratification from May-June until the end of September (Caramujo \& Boavida, 2000).

\section{MATERIAL AND METHODS}

Maranhão and Santa Luzia reservoirs were sampled at the deepest station (close to the dam), during the same day and within a few hours to ensure similar meteorological conditions. Samples were taken at the beginning of the fall mixing process, from September $25^{\text {th }}$ to November $26^{\text {th }} 2001$, every 8 12 days. This sampling design, based on shortterm surveys, is more adequate in zooplankton research programs for detecting changes in situations, such as autumn mixing that has been shown to occur very quickly (Robarts et al., 1982).

In situ temperature profiles were taken with a multiparametric probe YSI-56 from the surface to the bottom. Water transparency was measured 
with a black and white $20 \mathrm{~cm}$ Secchi disk. Average chlorophyll- $a$ concentration was measured in integrated samples taken at the surface, Secchi disk depth $\left(Z_{S D}\right)$ and twice Secchi disk depth $\left(2 Z_{S D}\right)$ which are depths that have been shown to be important for plankton distribution (Fernández Rosado et al., 1994). In the laboratory, samples were filtered $(1 \mathrm{~L})$ through Whatman GF/A filters for the determination of total chlorophyll- $a$ concentration. Total chlorophyll- $a$ was extracted in acetone over $24 \mathrm{~h}$ in darkness at about $8^{\circ} \mathrm{C}$. The final concentration was estimated spectrophotometrically, using Lorenzen's equations (Lorenzen, 1967). Integrated water samples were also collected, in acid-rinsed polyethylene bottles, to determine total phosphorus (TP) and soluble reactive phosphorus (SRP), following the standard methods (APHA, 1989).

Vertical hauls (from depths ranging between 13 and $24 \mathrm{~m}$ ) were performed in both study reservoirs during every survey for zooplankton sampling using a Wisconsin type net of $80 \mu \mathrm{m}$ mesh size (filtered volume ranging between 86 and $140 \mathrm{~L}$ ). The zooplankton sample was immediately anaesthetised with carbonated water and preserved in sugar-saturated formaldehyde ( $4 \% \mathrm{v} / \mathrm{v}$ final concentration). Once in the laboratory, the sample was analysed for counting the zooplankton of each selected group (rotifers, cladocerans and two copepod species, adults and juveniles of Copidodiaptomus numidicus and Acanthocyclops robustus). The dominant rotifers species are Keratella cochlearis hispida, Asplanchna priodonta, Polyarthra vulgaris, and Brachionus calyciflorus in Maranhão and Ploeosoma hudsoni and Collotheca mutabilis in Santa Luzia (Baião \& Boavida, 2005). Bosmina longirostris, Diaphanosoma brachyurum, and Daphnia hyalina $\times$ galeata are the cladocerans dominant species in Maranhão and Daphnia pulex, and Ceriodaphnia sp. in Santa Luzia (Caramujo \& Boavida 2000). Copepods are represented, apart from the two above mentioned species, by Thermocyclops dybowskii in Maranhão and by $T$. dybowskii and Macrocyclops albidus in Santa Luzia (Caramujo \& Boavida,
2000). However, during the sample period only Copidodiaptomus numidicus and Acanthocyclops robustus were present in both reservoirs. Moreover, prosome length, clutch size, and egg size were measured for female copepods. However, no females of the cyclopoid copepod carrying egg sacs were found. Therefore, all of the measurements were determined only for the calanoid $C$. numidicus, which was selected as an indicator for comparing both study reservoirs.

In addition to the data on population densities, and for detecting the effects of food $(f)$ and mate $(M)$ limitation on reproductive rates, the corresponding indexes developed by Williamson \& Butler (1987) were estimated:

$$
\begin{gathered}
f=\frac{G}{(N+G+O+B)} 100 \\
M=\frac{G}{(G+O+B)} 100
\end{gathered}
$$

where $N$ represents the non gravid and non ovigerous females; $G$ the gravid and non ovigerous females; $O$ the non-gravid and ovigerous females; and $B$ both gravid and ovigerous females. Finally, egg production rate (EPR, eggs female ${ }^{-1} \mathrm{~d}^{-1}$ ) was determined following Liang \& Uye (1997):

$$
E P R=\frac{C S}{\left(D_{E}+D_{I}\right)}
$$

where $C S$ is clutch size (number of eggs), $D_{E}$ is egg development time (in days) and $D_{I}$ is the time from hatching of old egg sacs to the production of new ones (in days). To estimate those values, the in situ sample temperature and the equations described in Caramujo \& Boavida (1999) for $C$. numidicus were used.

Spearman rank correlation test $\left(r_{s}\right)$ and MannWhitney $U$ test were used to detect interactions and differences in environmental variables (averaged values) and zooplankton densities between and within reservoirs. Results of statistical tests were declared significant when $p \leq 0.05$. 


\section{RESULTS}

Temperature and oxygen vertical profiles in the two reservoirs (Fig. 2) were typical of warm monomictic lakes in this region at this time of the year. In Maranhão, temperature ranged, during the sampling period, between 21.5 and $13.1{ }^{\circ} \mathrm{C}$ at the surface and between 19 and $11^{\circ} \mathrm{C}$ at the bottom. In Santa Luzia temperature ranged from 19.1 to $9.4^{\circ} \mathrm{C}$ at the surface and from 15.0 to $9.1^{\circ} \mathrm{C}$ at the bottom. Thermal stratification was broken in both reservoirs during the study period and both were totally mixed on the last sampling date. Dissolved oxygen profiles follow the thermal cycle showing a vertical clinograde pattern throughout the stratification period, while the homogeneous vertical profile was observed at the end of study period. Anoxic conditions (values below $1 \mathrm{mg} \mathrm{L}^{-1}$ ) were detected in Maranhão reservoir during the stratification period, but only occasionally in Santa Luzia.

The result of the Spearman rank correlation test showed that the patterns of chlorophyll- $a$ concentrations were similar in both reservoirs $\left(r_{s}=0.96\right.$; $p=0.001$; Fig. 3), with an increase at the beginning of the sampling period and a decrease towards the end. Chlorophyll- $a$ concentration in Maranhão was higher than in Santa Luzia during the whole study period except the last day of sampling. No relation was found between
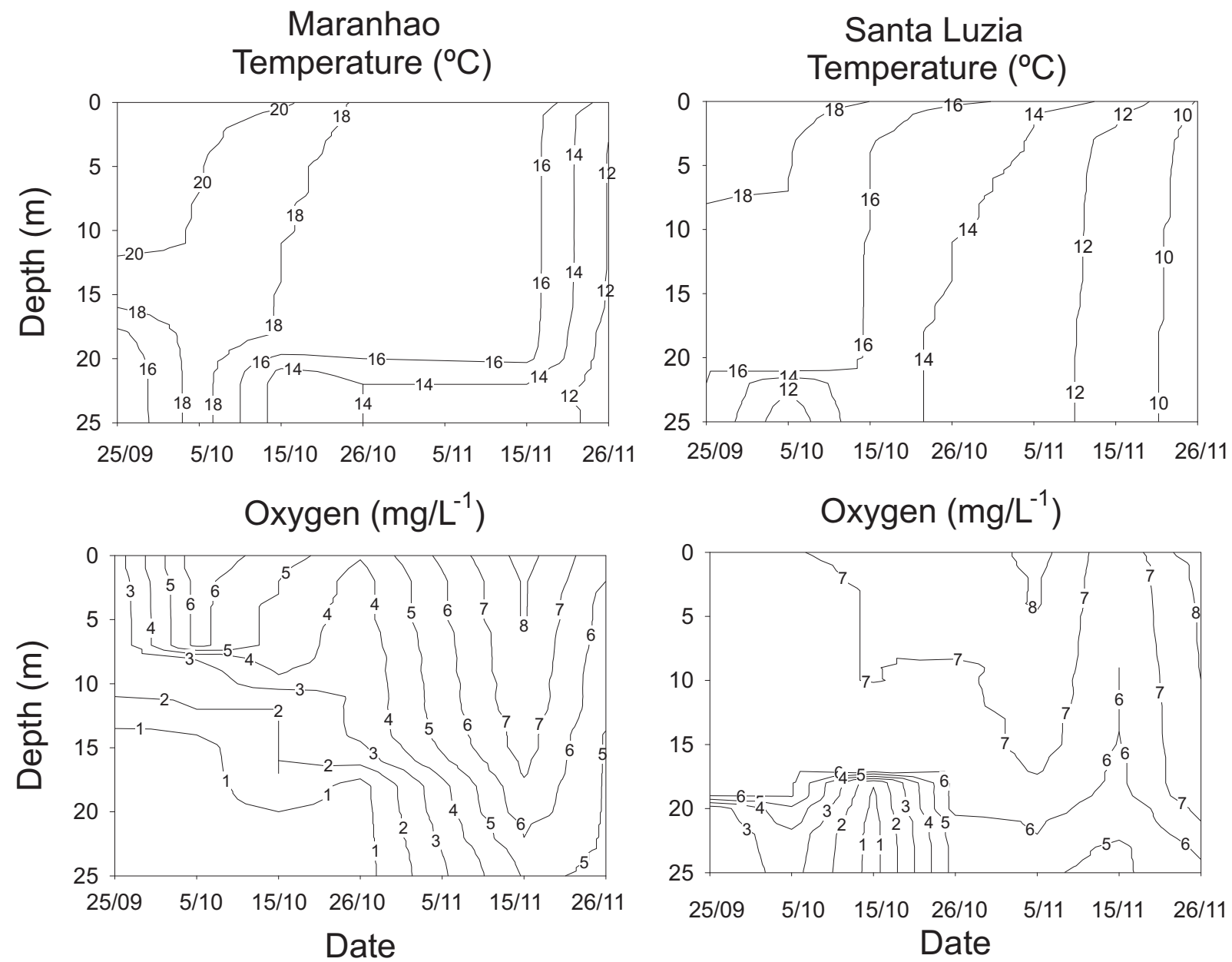

Figure 2. Temperature and oxygen profiles from both the Maranhão and Santa Luzia reservoirs during the sampling period. Perfiles de temperatura y oxígeno en los embalses de Maranhão y Santa Luzia durante el periodo de muestreo. 


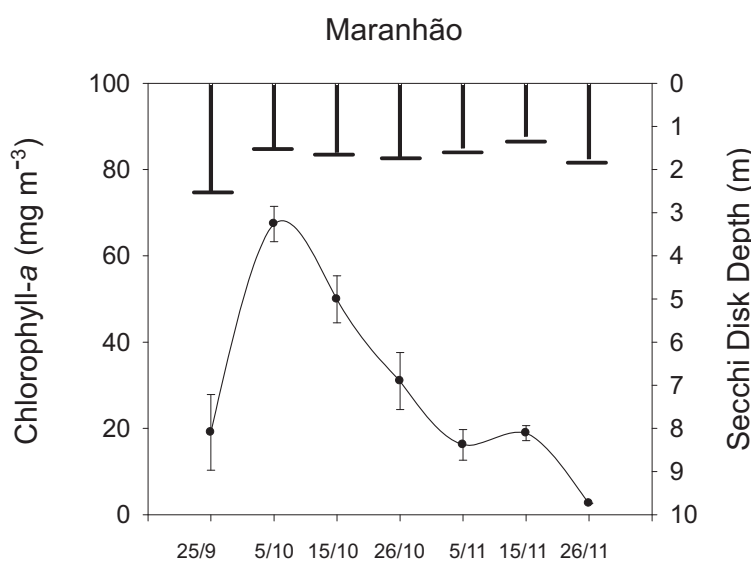

$p=0.35)$. Finally, as Table 1 shows, Santa Luzia exhibits lower TP and SRP concentrations than Maranhão (Mann-Whitney $U$ test; $p<0.05$ ).

Rotifer, cladoceran, and copepod densities were lower in Santa Luzia than those observed in Maranhão. Although the small rotifers and nauplii could be underestimated due to mesh size $(80 \mu \mathrm{m})$, the zooplankton density patterns were similar in both reservoirs, with a decrease at mid sampling period, just before the total mixing of the water column (Fig. 4). Copepod communities were composed of the cyclopoid A. robustus
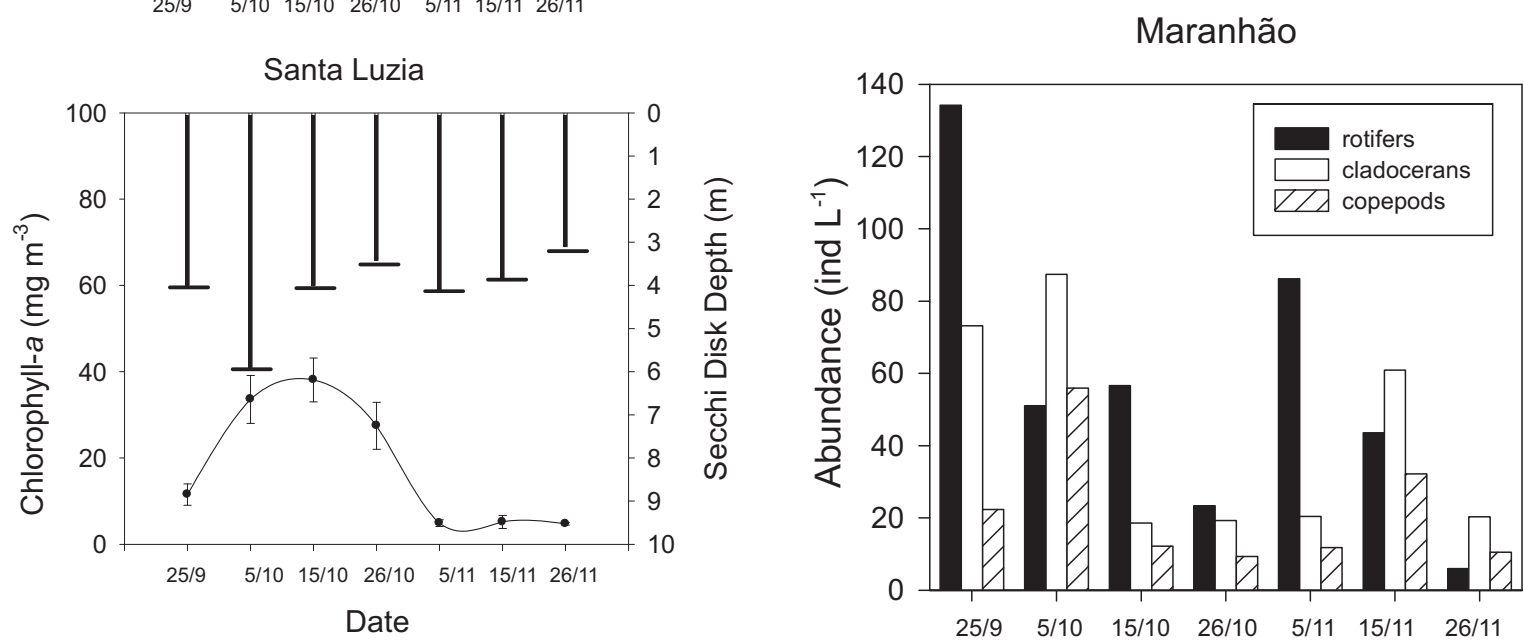

Figure 3. Chlorophyll- $a$ and Secchi disk depth values in the Maranhão and Santa Luzia reservoirs during the sampling period. Valores de clorofila-a y profundidad del disco de Secchi en los embalses de Maranhão y Santa Luzia durante el periodo de muestreo.

water transparency (Fig. 3) and chlorophyll-a concentrations in either reservoir (Maranhão, $r_{s}=-0.05, p=0.91 ;$ Santa Luzia, $r_{s}=0.41$,

Table 1. Mean, maximum and minimum values of nutrients (TP, total phosphorus and SRP, soluble reactive phosphorus; $n=$ 7) for the Maranhão and Santa Luzia reservoirs during the study period. Media y valores máximos y mínimos de nutrientes (TP, fósforo total y SRP, fósforo soluble reactivo; $\mathrm{n}=7$ ) para los embalses de Maranhão y Santa Luzia durante el periodo de estudio.

\begin{tabular}{ccc}
\hline Characteristics & $\begin{array}{c}\text { Maranhão } \\
\text { Mean (Min.-Max.) }\end{array}$ & $\begin{array}{c}\text { Santa Luzia } \\
\text { Mean (Min.-Max.) }\end{array}$ \\
\hline $\mathrm{TP}\left(\mu \mathrm{g} \mathrm{L}^{-1}\right)$ & $55.4(36.5-84.0)$ & $20.9(17.3-27.6)$ \\
$\mathrm{SRP}\left(\mu \mathrm{g} \mathrm{L}^{-1}\right)$ & $14.7(9.5-32.9)$ & $4.8(3.5-5.9)$ \\
\hline
\end{tabular}

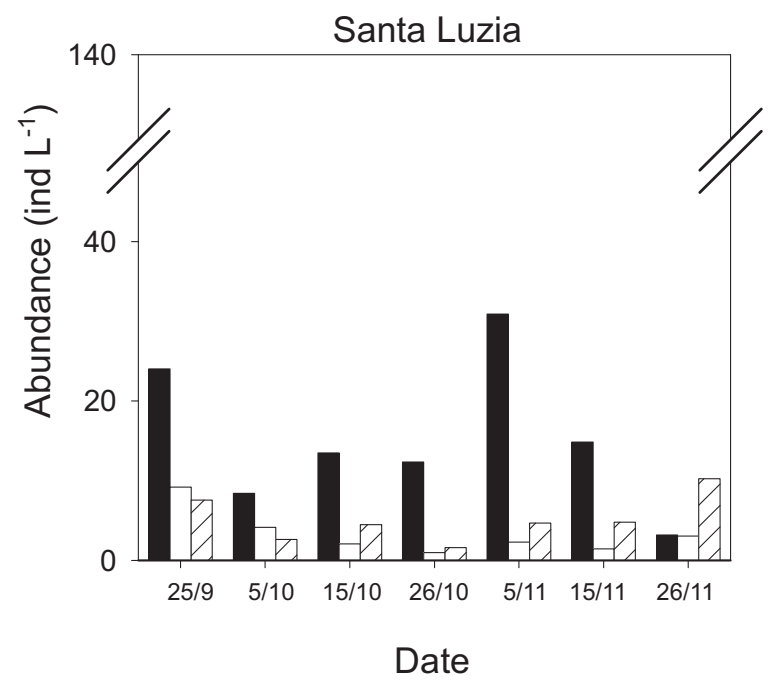

Figure 4. Rotifer, cladoceran, and copepod densities in the Maranhão and Santa Luzia reservoirs during the sampling period. Densidades de rotíferos, cladóceros y copépodos en los embalses de Maranhão y Santa Luzia durante el periodo de тиеstreo. 

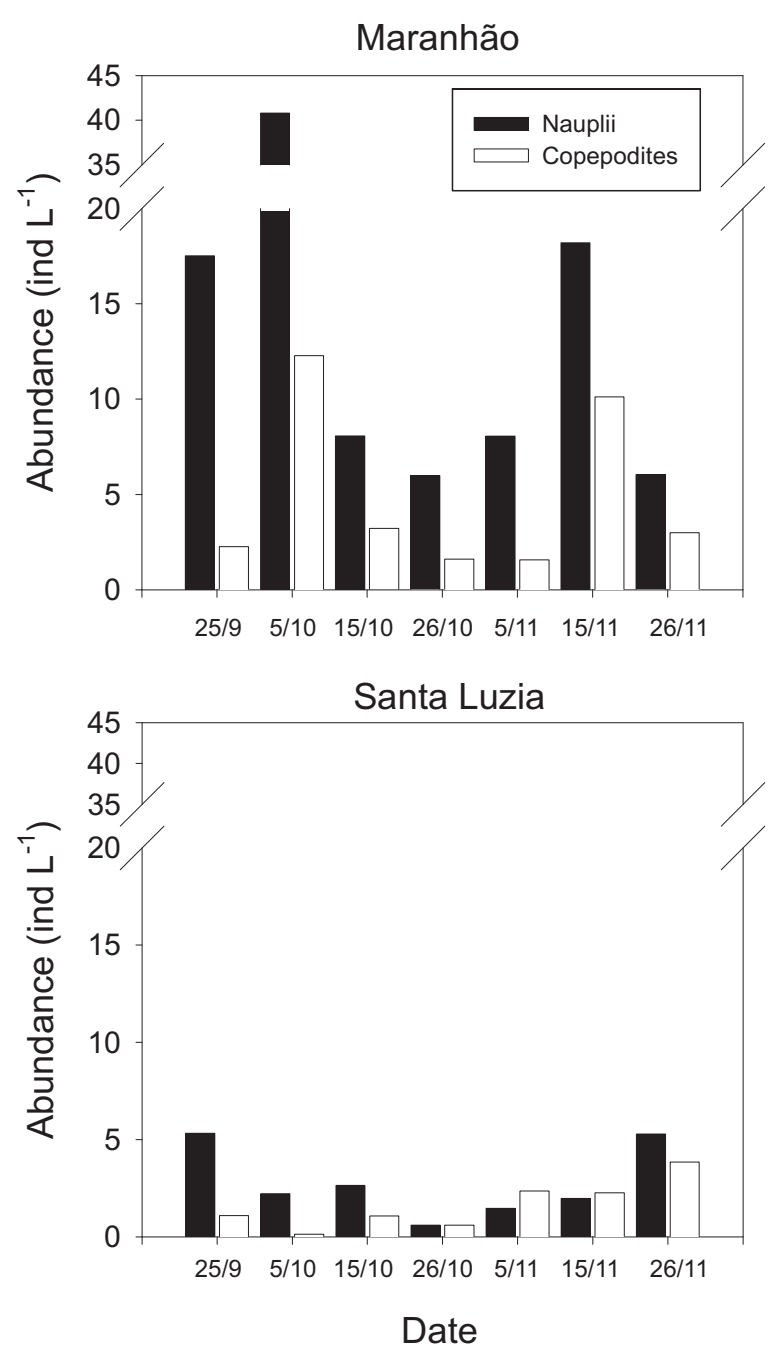

Figure 5. Nauplii and copepodites densities in the Maranhão and Santa Luzia reservoirs during the sampling period. Densidades de nauplius y copepoditos en los embalses de Maranhão y Santa Luzia durante el periodo de estudio.

and the calanoid $C$. numidicus in both reservoirs. Densities of both copepod species were generally higher in Maranhão than in Santa Luzia (Fig. 5 and $6 \mathrm{a}, \mathrm{b})$. The $C$. numidicus densities showed a considerable decrease at mid sampling period in both reservoirs, but this decrease was not so evident in A. robustus. No relationships were detected between the abundance of any species or stage and temperature or chlorophyll- $a$ data in either reservoir (Spearman correlations; $p>0.05$ ). Figure $6 \mathrm{c}$ shows the ratio calanoida:cyclopoida for both reservoirs, which was much lower in $\mathrm{Ma}-$ ranhão than in Santa Luzia reservoir.
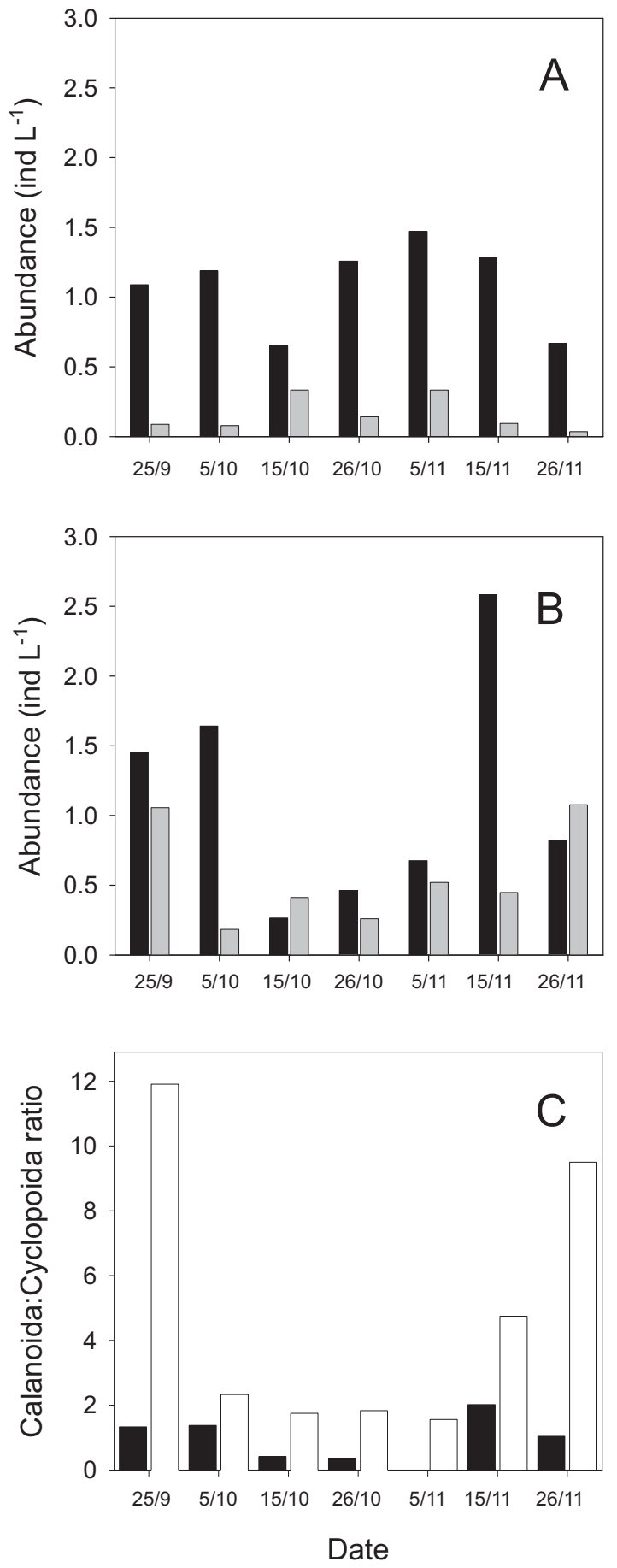

Figure 6. A. robustus (A) and C. numidicus (B) densities and calanoida:cyclopoida ratio (C) in the Maranhão (black bars) and Santa Luzia (white bars) reservoirs during the sampling period. Densidades de A. robustus (A) y C. numidicus (B) y razón calanoida:cyclopoida $(C)$ en los embalses de Maranhão (barras negras) y Santa Luzia (barras blancas) durante el periodo de mиеstreo. 
Table 2. Mean and standard deviation values of female prosome length, clutch size, and egg size of $C$. numidicus in the Maranhão and Santa Luzia reservoirs during the study period. Valores medios y desviación típica de la longitud del prosoma en hembras, tamaño de puesta y tamaño de huevos de C. numidicus en los embalses de Maranhão y Santa Luzia durante el periodo de estudio.

\begin{tabular}{lcc}
\hline & $\begin{array}{c}\text { Maranhão } \\
\text { Mean }( \pm \text { S.D. })\end{array}$ & $\begin{array}{c}\text { Santa Luzia } \\
\text { Mean }( \pm \text { S.D. })\end{array}$ \\
\hline Female prosome length $(\mathrm{mm})$ & $1.52( \pm 0.10)$ & $1.41( \pm 0.14)$ \\
Clutch size $\left(\mathrm{n}^{\circ}\right.$ eggs $)$ & $9.24( \pm 1.47)$ & $6.86( \pm 3.09)$ \\
Egg size $(\mathrm{mm})$ & $0.09( \pm 0.01)$ & $0.11( \pm 0.01)$ \\
\hline
\end{tabular}

As it has been already mentioned, females of A. robustus carrying eggs were not observed in many of the samples, making the calculation of the food and mate indexes and the egg production rate impossible, being calculated only for $C$. numidicus. Food $(f)$ and mate $(M)$ indexes were lower in Maranhão than in Santa Luzia during most of the study period (Fig. 7a). As a consequence, $C$. numidicus egg production rates (EPR) were higher in Maranhão than in Santa Luzia (Mann-Whitney $U$ test, $Z=-3.01, p=0.003$ ), although EPR tended to be similar for both reservoirs towards the end of the sampling period, after thermal stratification disruption (Fig. 7b). No relationships were detected between EPR and temperature or chlorophyll- $a$ in both reservoirs (Spearman correlations; $p>0.05$ ). Table 2 shows the mean values of female prosome length, clutch size and egg size during the study period in both reservoirs. $C$. numidicus females' length were not different between reservoirs (MannWhitney $U$ test, $Z=-1.29, p=0.20$ ) as well as clutch size (Mann-Whitney $U$ test, $Z=1.59$, $p=0.11$ ), while egg size showed significant differences between reservoirs (Mann-Whitney $U$ test, $Z=-2.02, p=0.043$ ).

\section{DISCUSSION}

It is well-known that both, composition and density of zooplankton communities change with trophic state (Maier, 1996). The zooplankton community - with a dominance of rotifers - a higher total zooplankton density, and a lower ra-
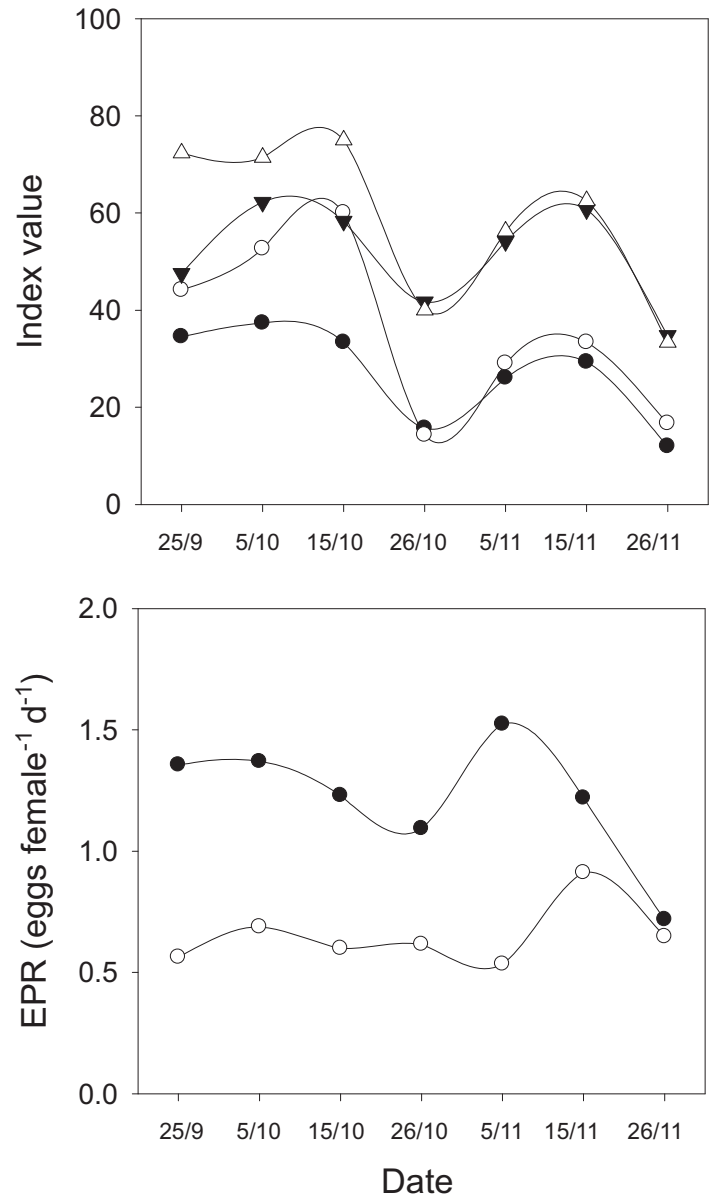

Figure 7. Variation of the food $(f$; circles $)$ and mate $(M$; triangles; A) limitation indexes, and egg production rates $(\mathrm{EPR} ; \mathrm{B})$ obtained with females of $C$. numidicus in the Maranhão (black) and Santa Luzia (white) reservoirs during the sample period. Variación en los índices de limitación por alimento (f; círculos) y de apareamiento ( $M$; triángulos; A) y tasa de producción de huevos $(E P R ; B)$, obtenidos a partir de hembras de C. numidicus en los embalses de Maranhão (negro) y Santa Luzia (blanco) durante el periodo de estudio.

tio calanoid to cyclopoid copepod in eutrophic reservoir, together with the values of water transparency, chlorophyll- $a$, and TP concentrations reported in the present study confirm the previous valoration of an oligotrophicmesotrophic state for Santa Luzia reservoir and a meso-eutrophic state for Maranhão reservoir (Brogueira \& Pereira, 1988; Marques \& Boavida, 1993; 1997; Baião \& Boavida, 2005).

Autumn circulation is one of the main events occurring annually in freshwater ecosystems, 
being also considered as one of the physical processes acting on plankton seasonality and plankton size-spectrum (Álvarez-Cobelas et al., 2005a; Álvarez-Cobelas et al., 2006b). Zooplankton dynamics, during the early circulation in lakes, appeared in the PEG model (Sommer et al., 1986) principally controlled by water temperature, fish predation, and edible items of phytoplankton. Contrary to what was expected, the abundance of zooplankton populations was not related to water temperature in this study. This result is consistent with the idea that in Mediterranean lakes, temperature has a minor effect on zooplankton dynamics than in cold temperate environments (Álvarez-Cobelas et al., 2005b). However, zooplankton abundance is much lower than those registered in other temperate lakes (Fussmann, 1993) or in other Mediterranean lakes (ÁlvarezCobelas et al., 2006a) in similar study periods.

On the other hand, EPR have been shown to be a useful tool in the determination of the factors that control the production and dynamics of planktonic copepod populations (Peterson et al., 1991). Consistent with this, EPR has also been correlated with physical and biological factors (Bautista et al., 1994; Rodríguez et al., 1995). In this sense, EPR is the product of two components: clutch size, which ultimately depends on temperature, food supply and the body size of adult female, and interclutch duration (Makino \& Ban, 2000). The higher EPR values and densities of the calanoid copepod $C$. numidicus in the Maranhão reservoir, confirm the effect that over this species generates the meso-eutrophic conditions, with values in the same range of those reported in literature for freshwater copepods (Hopp et al., 1997; Makino $\&$ Ban, 2000). The higher C. numidicus EPR found in Maranhão reservoir could be then related with: (i) the larger body size of females (no statistical differences were found in this study between reservoirs); (ii) the higher temperature of the water, which would induce shorter development periods and larger clutches, and (iii) a better food availability in this reservoir corroborated by the higher values of chlorophyll- $a$ obtained. However, we did not find any significant relationship between EPR and temperature or chlorophyll- $a$ concentration values.

In addition, the fact that zooplankton abundance was not correlated with chlorophyll- $a$ concentration suggests that other sources of food, such as non living organic matter, could play an important role in zooplankton dynamics during this period in the Maranhão and Santa Luzia reservoirs. Similar results have been previously reported by Gliwicz (2003) and ÁlvarezCobelas et al. (2006a), suggesting that others factors, such as competition and predation, must be involved as dominant causes for the observed patterns in zooplankton dynamics studies during the early circulation in lakes.

Finally, the fish community is very similar in both reservoirs, with the presence of Chondrostoma polylepis, Barbus sp., and Cyprinus carpio as important species (Quadrado, 1990). Most of these can be planktivorous, not only in the adult stage but also during the juvenile and larval stages. However, the predatory hypothesis should be confirmed through other studies in order to know the effects of fish predation during these periods and during periods not related with the breakdown of thermal stratification.

In conclusion, the lack of a relationship between zooplankton (abundance and reproductive rates) and temperature and chlorophyll- $a$ concentration, irrespective of the trophic state of the ecosystems during the autumn circulation period, may suggest a complex array of abiotic and biotic factors involved in zooplankton dynamics during that particularly variable period of the year.

\section{ACKNOWLEDGEMENTS}

During this study G. Parra was supported by a Junta de Andalucía grant (Ayudas a la Investigación. Estancias Breves. Resolución 2001). This work was also supported in part by the Comisión Interministerial de Ciencia y Tecnología, Spain (CICYT Project PB98-0307) and by the Centro de Biologia Ambiental, Universidade de Lisboa, Portugal. 


\section{REFERENCES}

ÁlVAREZ-COBELAS, M., J. L. VELASCO, M. VALLADOLID, A. BALTANÁS \& C. ROJO. 2005a. Daily patterns of mixing and nutrient concentrations during early autumn circulation in a small sheltered lake. Freshwat. Biol., 50: 813-829.

ÁLVAREZ-COBELAS, M., C. ROJO \& D. G. ANGELER. 2005b. Mediterranean limnology: current status, gaps and the future. J. Limnol., 64: 13-29.

ÁLVAREZ-COBELAS, M., A. BALTANÁS, J. L. VELASCO \& C. ROJO. 2006a. Zooplankton dynamics during autumn circulation in a small, wind-sheltered, Mediterranean lake. Mar. Freshwat. Res., 57: 441-452.

ÁLVAREZ-COBELAS, M., C. ROJO, J. L. VELASCO \& A. BALTANÁS. 2006b. Factors controlling planktonic size spectral responses to autumnal circulation in a Mediterranean lake. Freshwat. Biol., 51: 131-143.

ANDREW, T. E. \& A. G. FITZSIMMONS. 1992. Seasonality, population dynamics and production of planktonic rotifers in Lough Neagh, Northern Ireland. Hydrobiologia, 246: 147-164.

APHA. 1989. Standard methods for the examination of water and wastewater. Washington: American Public Health Association. 1268 pp.

BAIÃO, C. \& M. J. BOAVIDA. 2005. Rotifers of Portuguese reservoirs in river Tejo catchment: relations with trophic state. Limnetica, 24: 103-114.

BAUTISTA, B., R. P. HARRIS, V. RODRÍGUEZ \& F. GUERRERO. 1994. Temporal variability in copepods fecundity during two different spring bloom periods in coastal waters off Plymouth (SW England). J. Plankton Res., 16: 1367-1377.

BROGUEIRA, M. J. \& H. PEREIRA. 1988. Seasonal and spatial variability of the physicochemical characteristics of deep Maranhão reservoir, south of Portugal. Archiv für Hydrobiol., 113: 501-518.

CARAMUJO, M. J. \& M. J. BOAVIDA. 1999. Characteristics of the reproductive cycles and development times of Copidodiaptomus numidicus (Copepoda: Calanoida) and Acanthocyclops robustus (Copepoda: Cyclopoida). J. Plankton Res., 21: 1765-1778.

CARAMUJO, M. J. \& M. J. BOAVIDA. 2000. The crustacean communities of river Tagus reservoirs. Zooplankton structure as reservoir trophic state indicator. Limnetica, 18: 37-56.

FERNÁNDEZ-ROSADO, M. J., J. LUCENA \& F. X. NIELL. 1994. Space-time heterogeneity of the chlorophyll-a distribution in La Concepción reservoir (Istán, Málaga). Representative models. Archiv fur Hydrobiol., 129: 311-325.

FUSSMANN, G. 1993. Abundance, succession and morphological variation of planktonic rotifers during autumnal circulation in a hypertrophic lake (Heiligensee, Berlin). Hydrobiologia, 255/256: 353-360.

GLIWICZ, Z. M. 2003. Between hazards of starvation and risk of predation: the ecology of offshore animals. Excellence in ecology, Book 12. International Ecology Institute, Oldendorf/Luhe. 379 pp.

GUERRERO, F., S. NIVAL \& P. NIVAL. 1997. Egg production and viability in Centropages typicus: a laboratory study on the effect of food concentration. J. Mar. Biol. Ass. UK, 77: 257-260.

HOPP, U., G. MAIER \& R. BLEHER. 1997. Reproduction and adult longevity of five species of planktonic cyclopoid copepods reared on different diets: a comparative study. Freshwat. Biol., 38: 289-300.

JIMÉNEZ-MELERO, R., B. SANTER \& F. GUERRERO. 2005. Embryonic and naupliar development of Eudiaptomus gracilis and Eudiaptomus graciloides at different temperatures: comments on individual variability. J. Plankton Res., 27: 11751187.

JIMÉNEZ-MELERO, R., G. PARRA, S. SOUISSI \& F. GUERRERO. 2007. Post-embryonic developmental plasticity of Arctodiaptomus salinus (Copepoda:Calanoida) at different temperatures. $J$. Plankton Res., 29: 553-567.

LIANG, D. \& S. UYE. 1997. Seasonal reproductive biology of the egg-carrying calanoid copepod Pseudodiaptomus marinus in a eutrophic inlet of the Inland Sea of Japan. Mar. Biol., 128: 409-414.

LORENZEN, C. J. 1967. Determination of chlorophyll and phaeopigments: spectrophotometric equations. Limnol. Oceanogr., 12: 343-346.

MAIER, G. 1996. Copepod communities in lakes of different trophic degree. Archiv für Hydrobiol., 136: 455-465.

MAKINO, W. \& S. BAN. 2000. Response of life history traits to food conditions in a cyclopoid copepod from an oligotrophic environment. Limnol. Oceanogr., 45: 396-407.

MARQUES, R. T. \& M. J. BOAVIDA. 1993. Effects of the water level fluctuation on the forms of phosphorus in mesotrophic Maranhão Reservoir. Verh. Internat. Verein. Limnol., 25: 1207-1209. 
MARQUES, R. T. \& M. J. BOAVIDA. 1997. Monitoring water quality in two Portuguese reservoirs of the River Tejo watershed. Verh. Internat. Verein. Limnol., 26: 740-744.

PETERSON, W. T., P. TISELIUS \& T. KIORBOE. 1991. Copepod egg production, moulting and growth rates, and secondary production, in Skagerrak in August 1988. J. Plankton Res., 13: 131-154.

QUADRADO, M. F. L. 1990. The reservoirs of the river Tejo catchment - a bibliographic review. Direcção Geral dos Recursos Naturais. Lisboa. 183 pp.

ROBARTS, R. D., P. J. ASHTON, J. A. THORNTON, H. J. TAUSSIG \& L. M. SEPHTON. 1982. Overturn in a hypertrophic, warm, monomictic impoundment (Hartbeespoort Dam, South Africa). Hydrobiologia, 97: 209-224.
RODRÍGUEZ, V., F. GUERRERO \& B. BAUTISTA. 1995. Egg production of individual copepods of Acartia grani Sars from coastal waters: seasonal and diel variability. J. Plankton Res., 17: 22332250.

SOMMER, U. 1989. Toward a Darwinian ecology of plankton. In: Plankton ecology, succession in plankton communities. U. Sommer (ed.): 1-8. Springer.

SOMMER, U., Z. M. GLIWICZ, W. LAMPERT \& A. DUNCAN. 1986. The PGE-model of seasonal succession of planktonic events in fresh waters. Archiv für Hydrobiol., 106: 433-471.

WILLIAMSON, C. E. \& N. M. BUTLER. 1987. Temperature, food and mate limitation of copepod reproductive rates: separating the effects of multiple hypotheses. J. Plankton Res., 9: 821-836. 


\section{INSTRUCCIONES PARA LOS AUTORES}

Ámbito de publicación de Limnetica

Limnetica publica artículos originales de investigación sobre la ecología de las aguas continentales. El ámbito de publicación de Limnetica incluye la ecología de ríos, lagos, embalses, lagunas costeras, zonas húmedas, biogeoquímica, paleolimnología, desarrollo de metodologías, taxonomía, biogeografía y todos los aspectos de la ecología acuática continental teórica y aplicada como gestión y conservación, evaluación de impactos, ecotoxicología y contaminación. Por este motivo Limnetica aceptará para su publicación artículos científicos presentando avances del estado del conocimiento, de desarrollo tecnológico así como los que resulten de aplicaciones prácticas novedosas en las especialidades de interés de la revista.

\section{Presentación de manuscritos}

Los autores interesados deberán enviar un manuscrito vía e-mail al Editor de la revista (jarmengol@ub.edu). También se podrá enviar por correo ordinario un original más dos copias en papel y una en soporte magnético (CD, DVD o similares) al Editor de la revista. La copia en soporte informático estandarizado incluirá un fichero único con el texto, las tablas y las figuras según las presentes normas de publicación. Este fichero estará en un editor de textos compatible con un ordenador tipo PC (preferentemente Word, o programa compatible).

Tanto los originales impresos como las copias en soporte magnético se realizarán en hojas tipo A-4 y estarán escritos a doble espacio. Los artículos no sobrepasarán las 6000 palabras en el texto ni 25 hojas impresas (incluidas figuras y tablas) y podrán estar escritos en castellano o en inglés. Excepcionalmente, y previa consulta con el Editor, se podrán presentar manuscritos de mayor longitud que versen sobre revisiones generales, sistemática de grupos taxonómicos amplios o estudios regionales comparativos de un mismo tipo de ecosistemas acuáticos. No se aceptaran aquellos trabajos que no cumplan las presentes instrucciones de publicación.

El Comité Editorial de Limnetica decidirá sobre la publicación o no de los trabajos recibidos, e informará de ello a los autores. Los autores recibirán antes de su publicación una copia de las primeras pruebas de imprenta de su trabajo para su corrección. Una vez publicado el trabajo, el autor responsable de la publicación recibirá una copia en formato pdf.

\section{Estructura del manuscrito}

Todas las palabras en MAYÚSCULAS se acentuarán tanto en el TÍTULO como en los apartados (INTRODUCCIÓN, etc.)

La primera página del manuscrito ha de contener los siguientes apartados:

- Título en mayúsculas.

- Relación de autores con indicación del autor responsable a efectos de la correspondencia. Se deberá indicar expresamente la dirección e-mail de dicho autor.

- Dirección postal completa de los autores.

- Título abreviado.

La segunda página incluirá el Resumen en castellano, palabras clave, el Abstract en inglés y keywords. Tanto el Resumen como el Abstract no deberán sobrepasar las 400 palabras y deberán incluir el título del trabajo en el idioma correspondiente.

Las siguientes páginas se ordenarán en apartados que se estructurarán al estilo científico. Los apartados y párrafos del texto comenzarán sin sangrado. Se acentuarán las mayúsculas en todos los casos.

Los apartados se escribirán sin numerar y se escalarán según el siguiente formato:

Apartado primario.- Mayúsculas y en negrita (INTRODUCCIÓN)

Apartado secundario.- Minúsculas y en negrita.

Apartado terciario.- Itálica.

Apartado de cuarto nivel.- Letra normal subrayada.

Siguientes niveles.- numéricos (1), (1.1), (1.1.1), etc.

Las Tablas constituyen una de las partes más costosas en tiempo y presupuesto por lo que se ruega se preparen procurando ocupar el mínimo espacio posible. Las tablas pueden tener la anchura de una columna $(8 \mathrm{~cm}) \mathrm{o}$ dos columnas $(16 \mathrm{~cm})$ y su longitud no puede exceder de $25 \mathrm{~cm}$. Se incluirán al final del manuscrito y tendrán numeración arábiga. En el texto siempre se citarán de forma completa (p.e. Según se puede ver en la Tabla $6 \ldots$ etc. o, Los datos (Tabla 6) indican que... etc.) y nunca en forma abreviada -Tab. 6 o tab. 6. Las leyendas de las tablas se presentarán en castellano e inglés y se incluirán en el mismo apartado que el texto de las figuras. No deberán usarse líneas verticales y los encabezamientos de las columnas deberán ser breves. Se prestará particular atención en no publicar tablas que dupliquen información que ya está en forma de figuras.

Las figuras tendrán numeración arábiga con el texto explicativo en el pie. El texto incluirá la versión en castellano y en inglés. Las figuras pueden ir a tres tipos de caja $8,12.5$ y $16 \mathrm{~cm}$. Los autores procurarán que los originales tengan el tamaño de letra y el grueso de línea necesario para que al reducirse puedan ser interpretables y legibles. No se aceptarán figuras que no cumplan este requisito.

Los pies de figura, junto con los encabezamientos de las tablas, estarán en una página aparte situada inmediatamente después de la bibliografía y antes de las tablas y figuras.

Las citas de las figuras en el texto se harán de forma completa y en minúscula cuando se inserte dentro del texto de un párrafo (p.e. En la figura 1 se indica la situación de los puntos de muestreo). Por el contrario, se citará de forma abreviada y en mayúscula cuando esté entre paréntesis y no relacionada directamente con el texto del párrafo [p.e. Las muestras se han recogido en cinco estaciones distribuidas a lo largo del río (Fig. 1) y con una periodicidad mensual]. Las figuras y fotografías en color sólo se aceptarán de forma excepcional y previa consulta con el Editor.

Las unidades se expresaran preferiblemente en el Sistema Internacional (S.I.) con los símbolos en forma abreviada cuando vayan precedidos de una expresión numérica. Cuando se exprese un valor como combinación de dos unidades éstas se indicarán con el signo aritmético correspondiente p.e. m/s, $\mathrm{mol} / \mathrm{m}^{3}$, ind $/ \mathrm{l}$, pero para más de dos unidades se usarán exponentes, p.e. $\mathrm{m} / \mathrm{s}$, $\mathrm{mol} / \mathrm{m}^{3}$ ind $/ \mathrm{l}$, pero para más de dos unidades se usarán exponentes, p.e. $\mathrm{mgC}$ $\mathrm{m}^{-2} \mathrm{~h}^{-1} \mu \mathrm{mol} \mathrm{m} \mathrm{m}^{-1}$

Las cantidades con decimales se expresarán con un punto (4.36), los miles con cuatro números sin ninguna separación o símbolo (4392) y para valores iguales o superiores a las decenas de mil se intercalarán blancos separando los miles (13 723 o 132 437). Siempre que sea posible se indicarán los números con notación exponencial decimal con el mínimo posible de decimales (13.7 . $\left.10^{3}, 13.2 \cdot 10^{4}\right)$.

La BIBLIOGRAFÍA se ordenará al final del texto, alfabéticamente y cronológicamente para cada autor, según las pautas siguientes:

- Revistas:

RUEDA, F. J., E. MORENO-OSTOS \& J. ARMENGOL. 2006. The residence time of river water in reservoirs. Ecological Modelling, 191: 260275 .

GRAÇA M. A. S. \& C. CANHOTO. Leaf litter processing in low order streams. Limnetica, 25(1-2): 1-10.

RECHE, I. E. PULIDO-VILLENA, R. MORALES-BAQUERO \& E. O CASAMAYOR. 2005. Does ecosystem size determine aquatic bacterial richness? Ecology, 86: 1715-1722.

- Libro:

KALFF, J. 2002. Limnology. Prentice Hall. NJ. USA. 592 pp.

- Capítulo de libro:

IMBODEN, D. M. 1998. The influence of Biogeochemical Processes on the Physics of Lakes. In: Physical Processes in Lakes and Oceans. J. Iberger (ed.): 591-612. American Geophysical Union. Washington. USA.

- Congresos:

GEORGE, D. G. 2006. Using airborne remote sensing to study the mixing characteristics of lakes ans reservoirs.10th European Workshop on Physical Processes in Natural Waters. June 26-28, 2006. Granada, Spain: 2001-207.

- Informes:

DOLZ, J. \& E. VELASCO. 1990. Análisis cualitativo de la hidrología superficial de las cuencas vertientes a la marisma del Parque Nacional de Doñana (Informe Técnico). Universidad Politécnica de Cataluña. 152 pp.

- Tesis y Maestrias:

MORENO-OSTOS, E. 2004. Spatial dynamics of phytoplankton in El Gergal reservoir (Seville, Spain). Ph.D. Thesis. University of Granada. 354 pp. THOMPSON, K. L. 2000. Winter mixing dynamics and deep mixing in Lake Tahoe. Master's Thesis, University of California, Davis. 125 pp.

En el manuscrito se listarán únicamente los trabajos citados en el texto; en éste, las referencias se harán en minúsculas (Kalff, 2002; Dolz \& Velasco, 1991; Rueda et al., 2006). En ningún caso se aceptarán como referencias trabajos no publicados (p.e. en preparación) o aún no aceptados (p.e. enviado). Sí se podrán incluir citas de trabajos aceptados para su publicación (en prensa). Se recuerda la conveniencia de reducir al máximo las referencias bibliográficas de difícil consulta como informes, resúmenes a congresos, etc. 


\section{INSTRUCTIONS FOR AUTHORS}

Scope

Limnetica publishes original research papers on ecology of continental waters. Its scope includes ecology of rivers, lakes, reservoirs, lagoons and wetlands, biogeochemistry, paleolimnology, development of new methods, taxonomy, biogeography, and all aspects of theoretical and applied continental aquatic ecology, like management and conservation, impact assessment, ecotoxicology and pollution. Limnetica will accept for publication scientific papers presenting advances in knowledge or technological development, as well as papers derived from new practical approaches on the topics covered by the journal.

\section{Manuscript presentation}

Manuscripts must be submitted by e-mail to the journal Editor (jarmengol@ub.edu). Manuscripts also can be sent to the Editor by regular mail (original plus two hard copies and one digital copy. The digital copy must include a file with text, tables and figures following the present instructions, made with PC-compatible text-edition software (MSWord, Wordperfect, etc.).

Both hard and digital copies will be typed at double space on A-4 sheets. Papers can be written in Spanish or English, and must not exceed 6000 words of text nor 25 printed pages (figures and tables included). Exceptionally, and after consulting the Editor, longer manuscripts can be published for general reviews, systematics of broad taxonomic groups, or regional comparative studies of one kind of aquatic ecosystems. Papers that do not follow the present instructions will be rejected.

Limnetica's Editorial Board will decide whether to publish or not the received manuscripts, and will tell their decision to the authors. Prior to publication, authors will get galley proofs to be corrected. When the paper has been published, the leading author will get a copy in pdf format.

\section{Manuscript structure}

For manuscripts in Spanish, words in UPPER CASE will be accentuated when convenient, both in the title and section headings (INTRODUCCIÓN, etc.).

The first page must include:

- Title in upper case.

- List of authors detailing the corresponding author, whose e-mail address must be shown.

- Complete postal address of authors.

- Running title.

The second page will include Abstract and key words, both in English and Spanish. Abstracts must start with the title and not exceed 400 words.

Following pages must be structured in sections following the scientific style. Section headings and text will have no left indent. Upper case words in Spanish will be accentuated.

Sections and subsections will not be numbered, and must adjust to the following format:

Main section.- Bold, upper case (INTRODUCTION).

$2^{\text {nd }}$-level section.- Bold, lower case.

$3^{\text {rd }}$-level section.- Italics.

$4^{\text {th }}$-level section.- Plain text, underlined.

Lower-level sections.- They will go numbered (1), (1.1), (1.1.1), etc.

Tables are one of the most costly parts, both in terms of time and money; therefore, they must be drawn as compact as possible. Tables can be 1-column $(8 \mathrm{~cm})$ or 2-column $(16 \mathrm{~cm})$ wide, and their length cannot exceed $25 \mathrm{~cm}$. They will be included at the end of the manuscript and numbered in Arabic numbers. In the text they will be written in complete form (e.g., as can be seen in Table $6 . .$. , or Data (Table 6) show that...), never in abbreviated form (neither Tab. 6 nor tab. 6). Table captions will be written in both English and Spanish, and will be included in the text in the same section than Figure legends. No vertical lines can be drawn in tables, and column headings must be short. No table will be published that shows information presented in figures.

Figures will have Arabic numbers, and legends will go below, both in English and Spanish. Figures can fit three box-sizes: $8 \mathrm{~cm}, 12.5 \mathrm{~cm}$, or $16 \mathrm{~cm}$.
Authors must make sure that font size and line thickness can be easily read after reduction, otherwise figures will be rejected.

Figure legends and table captions will go in a page after Literature Cited and before Tables and Figures.

Figure calls must be made in complete, lower case form when in the text (e.g., Location of sampling sites is shown in figure 1), in abbreviated, upper case when going in a parenthesis and not directly related to the text [e.g., Samples were taken monthly at five sites along the river (Fig. 1)]. The Editor will accept to publish colour figures and photographs only exceptionally and when explicitly requested.

Units must be expressed preferably following the International System (I.S.), with abbreviated symbols when preceded by numeric expressions. Values combining two units must be expressed with the corresponding arithmetic sign, like $\mathrm{m} / \mathrm{s}, \mathrm{mol} / \mathrm{m}^{3}$, ind $/ \mathrm{l}$, but when there are more than two units exponentials must be used, like in $\mathrm{mgC} \mathrm{m}^{-2} \mathrm{~h}^{-1}, \mu \mathrm{mol} \mathrm{m} \mathrm{m}^{-2} \mathrm{~s}^{-1}$.

Decimal numbers will be expressed with a dot (4.36), thousands with 4 digits, with no blank space or symbols (4392), and figures over ten thousand will have blank space markings (13 723 or 132437 ). Whenever possible the scientific notation will be used, with the smallest possible number of decimals $\left(13.7 \cdot 10^{3}, 13.2 \cdot 10^{4}\right)$.

BIBLIOGRAPHY will be after the text, in alphabetic order, chronologically for each author, and adhere to the following style:

- Journals:

RUEDA, F. J., E. MORENO-OSTOS \& J. ARMENGOL. 2006. The residence time of river water in reservoirs. Ecological Modelling, 191: 260275 .

GRAÇA M. A. S. \& CRISTINA CANHOTO. Leaf litter processing in low order streams. Limnetica, 25(1-2): 1-10.

RECHE, I., E. PULIDO-VILLENA, R. MORALES-BAQUERO \& E. O CASAMAYOR. 2005. Does ecosystem size determine aquatic bacterial richness? Ecology, 86: 1715-1722.

- Books:

KALFF, J. 2002. Limnology. Prentice Hall. NJ. USA. 592 pp.

- Book chapters:

IMBODEN, D. M. 1998. The influence of Biogeochemical Processes on the Physics of Lakes. In: Physical Processes in Lakes and Oceans. J. Iberger (ed.): 591-612. American Geophysical Union. Washington. USA.

CASTRO, M., J. MARTIN-VIDE \& S. ALONSO. 2005. El clima de España: pasado, presente y escenarios de clima para el siglo XXI. In: Evaluación preliminar de los impactos en España por efecto del Cambio Climático. J. M. Moreno Rodríguez (ed.): 113-146. Ministerio de Medio Ambiente.

- Conferences:

GEORGE, D. G. 2006. Using airborne remote sensing to study the mixing characteristics of lakes ans reservoirs.10th European Workshop on Physical Processes in Natural Waters. June 26-28, 2006. Granada, Spain: 2001-207.

- Reports:

DOLZ, J. \& E. VELASCO. 1990. Análisis cualitativo de la hidrología superficial de las cuencas vertientes a la marisma del Parque Nacional de Doñana (Informe Técnico). Universidad Politécnica de Cataluña. 152 pp. - $\mathrm{PhD}$ and Master Dissertations:

MORENO-OSTOS, E. 2004. Spatial dynamics of phytoplankton in El Gergal reservoir (Seville, Spain). Ph.D. Thesis. University of Granada. $354 \mathrm{pp}$.

THOMPSON, K. L. 2000. Winter mixing dynamics and deep mixing in Lake Tahoe. Master's Thesis, University of California, Davis. 125 pp.

The Bibliography will only contain papers cited in the text, where they must go in lower case (Margalef, 1975; Wetzel \& Likens, 1991; Riera et al., 1992). In no case will unpublished (e.g., in prep., submitted) papers be cited, unless they are accepted for publication (in press). References to works hard to get (reports, conference abstracts, etc.) must be limited to the minimum possible. 